\title{
HUMAN RIGHTS FOR LIFE: EXPERIENCE OF UKRAINE
}

\section{Hromovchuk M. V., Rohach O. Ya.}

\section{INTRODUCTION}

According to Article 3 of the Constitution of Ukraine, man, his life and health, honour and dignity, inviolability and security are recognized in Ukraine as the highest social value ${ }^{1}$. Human life serves as the object of legal protection because it is the state that should create mechanisms that would maximally protect life from any encroachment.

Life is the greatest and most important social and legal benefit of a personality. As N. Matuzov notes, "the right to life is the first fundamental natural right of a person, without which all other rights lose meaning",2. Agreeing with the above-mentioned opinion, S. Chernychenko claims that "without the provision of the right to life, the question of observance of other rights and freedoms becomes a senseless" ${ }^{3}$.

The right of a person to life is very important in order to attract the attention of scientists. Such an aspect of the right to life as a death penalty is reflected in the works of A. Meziaiev, A. Malko, A. Nikyforov, V. Kartashkin, B. Tuzmukhamedov, T. Fomichenko, and other scholars. Works by A. Abashydze, Yu. Antonian, B. Ashavskyi, M. Biriukov, H. Veliaminov, S. Yehorov, B. Zymnenko, A. Kapustin, A. Kovalov, A. Kolodkin, V. Kotliar, A. Moiseiev, I. Lukashuk, Ye. Liakhov, N. Matuzov, Yu. Romashov, Yu. Rybakov, O. Khlestov, S. Chernychenko are devoted to the international legal aspect of the right to life. In the modern Ukrainian science, the following scholars devoted their papers to certain aspects of the right to life: M. Buromenskyi, V. Yevintov, V. Denysov, L. Zablotska and others.

\section{Statement of the basic material}

Regulations of the Criminal Code of Ukraine (hereinafter - CC of Ukraine) $^{4}$ on 05.04.2001 № 2341-III (as amended) do not contain

${ }^{1}$ Конституція України: Закон України від 28.06.1996 № 254к/96-ВР [Електронний pecypc] - Режим доступу : http://zakon2.rada.gov.ua/laws/show/254\%D0\%BA/96-\%D0\%B2\% D1\%80.

${ }^{2}$ Матузов Н. И. Право на жизнь в свете российских и международных стандартов / Н.И.Матузов // Правоведение. - 1998. - № 1. - Р. 26.

${ }^{3}$ Черниченко С.В. Еще раз о международной правосубъектности индивида / С.В.Черниченко // Московский журнал международного права, 2005. - № 4. - С. 16.

${ }^{4}$ Кримінальний кодекс України від 05.04.2001 року № 2341-III (із змінами та доповненнями) // (Відомості Верховної Ради України (ВВР), 2001, № 25-26, ст. 131). 
provisions on the mandatory consideration of decisions and legal positions of the Constitutional Court of Ukraine in the course of criminal proceedings. However, part 1 of Article 3 of the CC of Ukraine notes: legislation of Ukraine on criminal responsibility is the Criminal Code of Ukraine that is based on the Constitution of Ukraine and generally accepted principles and norms of international law.

One of the most important judgments in the practice of the Constitutional Court of Ukraine for criminal legal relations is Judgment on 29 December 1999 N 11-pп/99 known as Judgment on Death Penalty. In particular, in the operative part of the judgment, the Court ruled that the provisions of Article 24 of the General Part and the provisions of sanctions of articles of the Special Part of the Criminal Code of Ukraine, which provide for the death penalty as a form of punishment, shall be regarded as not in conformity with the Constitution of Ukraine (are unconstitutional) ${ }^{5}$. The mentioned decision N 11-pп/99 not only influenced criminal legal relations but also, in general, the status of Ukraine as a state moving towards recognizing and implementing the ideas of humanism.

On this occasion, it is important to draw attention to the legal substantiation and positions of the Constitutional Court of Ukraine, which are indicated in the above-mentioned judgment.

Consequently, the Court emphasizes that the Constitution of Ukraine recognizes the person, his/her life and health, honour and dignity, inviolability and safety as the highest social value (part one of Article 3), and the establishment and assurance of human rights and freedoms - the main responsibility of the state (part two of Article 3).

Interpretation of provisions of parts one and two of Article 27 of the Constitution of Ukraine in the context of all other provisions of the Constitution of Ukraine as a single holistic document gives grounds for asserting that they do not impose the death penalty as a form of punishment. In favour of such a conclusion, the tendency of the application of the Convention for the Protection of Human Rights and Fundamental Freedoms on the 1950 year ratified by the Verkhovna Rada of Ukraine (Law of Ukraine "On Ratification of the Convention on the Protection of Human Rights and Fundamental Freedoms, 1950, First Protocol and Protocols N 2, 4, 7 and 11 to the Convention” on 17 July

\footnotetext{
${ }^{5}$ Рішення Конституційного суду України у справі за конституційним поданням 51 народного депутата України щодо відповідності Конституції України (конституційності) положень статей 24, 58, 59, 60, 93, 190-1 Кримінального кодексу України в частині, що передбачає смертну кару як вид покарання (справа про смертну кару) [Електронний ресурс] - Режим доступу : http://zakon3.rada.gov.ua/laws/show/v011p710-99.
} 
1997, as amended by the Law of Ukraine on 24 March 1999, in particular, the provisions of Article 3 of the Convention) is evidenced ${ }^{6}$.

The key to recognizing the human right to life under the Constitution of Ukraine is the provision, according to which this right is inalienable (part one of Article 27), indefeasible, and inviolable (Article 21). The right to life belongs to a person from birth and is protected by the state.

\section{Constitution and right for life}

The Constitution of Ukraine declares that constitutional rights and freedoms, in particular, the right to life, are guaranteed and cannot be abolished (part 2 of Article 22), which prohibits any changes to the Constitution of Ukraine if they provide for the abolition of human rights and freedoms (part one of Article 157). It is also not allowed to narrow the content and scope of existing rights and freedoms, including the inalienable right to life, in the event of adoption of new ones or amendments to existing laws (part three of Article 22).

Consequently, in its content, the provisions of part 2 of Article 22 of the Constitution of Ukraine provide, on the one hand, the duty of the state to guarantee constitutional rights and freedoms, first of all, the right to life, and, on the other hand, to abstain from the adoption of any acts that would lead to the abolition of constitutional rights and freedoms, and hence human rights to life. Proceeding from the provisions of part two of Article 8 of the Constitution of Ukraine, the norm of part two of Article 22 shall be taken into account when adopting laws and other normative legal acts aimed at regulating the relevant social relations. The deprivation of a person's life by the state as a result of the use of the death penalty as a form of punishment, even within the limits set by the law, is the abolition of the inalienable human right to life, which does not correspond to the Constitution of Ukraine.

Therefore, the relevant provisions of the Criminal Code of Ukraine, which provide for the use of the death penalty, contradict the aforementioned provisions of the Constitution of Ukraine.

According to Article 23 of the Constitution of Ukraine, each person has a right to free personal development, provided that the rights and freedoms of other people are not violated. The Constitution of Ukraine, which enshrines the inalienable right to life of every person (part one of

\footnotetext{
${ }^{6}$ Про ратифікацію Конвенції про захист прав і основних свобод людини 1950 року, Першого протоколу та протоколів N 2, 4, 7 та 11 до Конвенції: Закон України від 17 липня 1997 року із змінами, внесеними Законом України від 24 березня 1999 року [Електронний pecypc] - Режим доступу: http://zakon2.rada.gov.ua/laws/show/475/97-\%D0\%B2\%D1\%80.
} 
Article 27) and protects this right from cancellation (part two of Article 22), establishes at the same time the provision that everyone has the right to protect their lives and health, life and health of other people from unlawful encroachment (part three of Article 27). In accordance with the provision of part 5 of Article 55 of the Constitution of Ukraine, everyone has the right, by any means not prohibited by law, to protect their rights and freedoms from violations and unlawful encroachments.

The Constitution of Ukraine does not contain any provisions on the possibility of using the death penalty as an exception to the provisions of part one of Article 27 of the Constitution of Ukraine on the inalienable right to life of every person. Thus, the death penalty as a form of punishment provided for in the relevant provisions of the Criminal Code of Ukraine cannot be considered an exception to the inalienable right to life of every person enshrined in the Constitution of Ukraine. Provisions of the Criminal Code of Ukraine on the use of death penalty as a form of punishment should be considered as not provided by the Constitution of Ukraine restrictions on the inalienable right to life of every person and should be recognized as inconsistent with the Constitution of Ukraine (unconstitutional).

Expanding the content of the inalienable right to life of every person, enshrined in part one of Article 27 of the Constitution of Ukraine, one should also take into account the non-compliance of the death penalty with the purposes of punishment and the possibility of a miscarriage of justice, when execution of a sentence against a person sentenced to death does not make it possible to correct its consequences, which is not in accordance with the constitutional guarantees of the protection of human rights and freedoms (Article 55 of the Constitution of Ukraine).

Given the fact that Ukraine is a social, democratic, and legal state (Article 1 of the Constitution of Ukraine), in which life and health, honour and dignity, inviolability and human security are recognized as the highest social value (Article 3 of the Constitution of Ukraine), the death penalty as a type of punishment should be considered as such, which does not comply with the specified provisions of the Constitution of Ukraine.

\section{The Criminal Code of Ukraine and right for life}

With regard to the provisions of Article 25 of the Criminal Code of Ukraine regarding the replacement of the death penalty with another form of punishment, this issue is subject to a decision in the legislative process (paragraph 14 of part one of Article 92 of the Constitution of Ukraine). 
The arguments put forward in its Judgment on Death Penalty, the Constitutional Court of Ukraine is an example of the Court's ability to use the gains from all possible sources (legal doctrine, political and legal representations, principles of constructing the modern world, international legal documents, moral principles, etc.) in order to substantiate its decision.

In the practice of courts of general jurisdiction, this Judgment No. 11-pn/99 and its legal positions are still used in our time. This is evidenced in particular by the decision of the High Specialized Court of Ukraine for Civil and Criminal Cases on 17 March 2016 ${ }^{7}$.

In criminal cases on review of newly discovered circumstances, convicted persons and their representatives use the Judgment of the Constitutional Court of Ukraine No. 11-рп/99 as arguments about the possibility of revision of decisions on condemnation, expressed in the motive parts of decisions of courts of general jurisdiction, in particular, in acts of higher courts, one can refer to the judgment of the High Specialized Court for Civil and Criminal Cases on 24 July $2015^{8}$, the judgment of the High Specialized Court for Civil and Criminal Cases on 14 April 2015 ${ }^{9}$, the judgment of the High Specialized Court for Civil and Criminal Cases on 13 November $2014^{10}$.

In this category of cases, in particular, those specified in the decision of the High Specialized Court for Civil and Criminal Cases on 13 November 2014, sentenced to life imprisonment, individuals apply to the courts of appeals with an application for review of the sentence for newly discovered circumstances, in which they raise the issue of the replacement of the imposed punishment for imprisonment for a specified period. In the justification of the above, it is noted that at the time of the commission of a crime in 1999, the sanction of Art. 93 of the CC of Ukraine (1960) provided for alternative sentences in the form of imprisonment for a term from 8 to 15 years or death penalty; by Judgment of the Constitutional Court of Ukraine No. 11-pп/99 on 29 December 1999, the provisions of

\footnotetext{
${ }^{7}$ Ухвала Вищого спеціалізованого суду із розгляду цивільних та кримінальних справ від 17 березня 2016 року [Електронний ресурс] // Режим доступу до ресурсу: http://www.reyestr.court.gov.ua/Review/56552340.

${ }^{8}$ Ухвала Вищого спеціалізованого суду із розгляду цивільних та кримінальних справ від 24 липня 2015 року[Електронний ресурс] // Режим доступу до ресурсу: http://www.reyestr.court.gov.ua/Review/47465255.

${ }^{9}$ Ухвала Вищого спеціалізованого суду із розгляду цивільних та кримінальних справ від 14 квітня 2015 року [Електронний ресурс] // Режим доступу до ресурсу: http://www.reyestr.court.gov.ua/Review/43626016

${ }^{10}$ Ухвала Вищого спеціалізованого суду із розгляду цивільних та кримінальних справ від 13 листопада 2014 року [Електронний ресурс] // Режим доступу до ресурсу: http://www.reyestr.court.gov.ua/Review/42766411.
} 
the sanctions of the Special Part of the Criminal Code of Ukraine (1960), which provided for the death penalty as a form of punishment, were declared unconstitutional, and the punishment in the form of life imprisonment was established only on the basis of the Law of Ukraine on 22 February 2000, № 1483-III, which entered into force on 4 April 2000. Based on the above, in the opinion of the convict, only the punishment in the form of imprisonment for a term up to 15 years was applied to him as such as envisaged by the sanction of Art. 93 of the CC of Ukraine (1960) as of 31 March 2000, that is, on the day of the sentence.

\section{CONCLUSIONS}

Thus, we believe that despite the contradiction in the current state of understanding of the concept of "legal positions of the Constitutional Court of Ukraine" by the scientific doctrine of constitutional law, they play a significant role in the establishment and consolidation of the rule of law and correct legal understanding in order to protect the rights and freedoms of man and citizen in Ukraine. The consistency of legal positions of the Constitutional Court of Ukraine is an important sign of ensuring the operation of principles of the constitutional jurisdiction body and principles of the Constitution of Ukraine, in particular, the need to ensure a unified legal understanding and methodological basis for the justification of a decision in one or another case, especially in the field of work of courts of general jurisdiction. The analysis of the rule-making activity of the decisions of the CCU gives grounds to say that the CCU in its decisions analyses only the signs and elements of the constitutional human right to life.

\section{SUMMARY}

The article reveals the peculiarities of the normative and legal consolidation of the human right to life. The authors pay attention to the provisions of the decisions of the Constitutional Court of Ukraine that carry out the interpretation of the human right to life.

\section{REFERENCES}

1. Конституція України: Закон України від 28.06.1996 № 254к/96-ВР [Електронний ресурс] - Режим доступу : http://zakon2.rada.gov.ua/ laws/show/254\%D0\%BA/96-\%D0\%B2\%D1\%80.

2. Матузов Н. И. Право на жизнь в свете российских и международных стандартов / Н.И.Матузов // Правоведение. - 1998. - № 1. C. 25-31. 
3. Черниченко С.В. Еще раз о международной правосубъектности индивида / С.В. Черниченко // Московский журнал международного права, 2005. - № 4. - С. 16-26.

4. Кримінальний кодекс України від 05.04.2001 року № 2341-III (із змінами та доповненнями) // (Відомості Верховної Ради України (BВP), 2001, № 25-26, ст. 131)

5. Рішення Конституційного суду України у справі за конституційним поданням 51 народного депутата України щодо відповідності Конституції України (конституційності) положень статей 24, 58, 59, 60, 93, 190-1 Кримінального кодексу України в частині, що передбачає смертну кару як вид покарання (справа про смертну кару) [Електронний ресурс] - Режим доступу : http://zakon3.rada.gov.ua/ laws/show/v011p710-99.

6. Про ратифікацію Конвенції про захист прав і основних свобод людини 1950 року, Першого протоколу та протоколів № № 2, 4, 7 та 11 до Конвенції: Закон України від 17 липня 1997 року із змінами, внесеними Законом України від 24 березня 1999 року [Електронний pecypc] - Режим доступу: http://zakon2.rada.gov.ua/laws/show/475/ 97-\%D0\%B2\%D1\%80.

7. Ухвала Вищого спеціалізованого суду із розгляду цивільних та кримінальних справ від 17 березня 2016 року [Електронний ресурс] // Режим доступу до ресурсу: http://www.reyestr.court.gov.ua/Review/ 56552340.

8. Ухвала Вищого спеціалізованого суду із розгляду цивільних та кримінальних справ від 24 липня 2015 року[Електронний ресурс] // Режим доступу до ресурсу: http://www.reyestr.court.gov.ua/Review/ 47465255.

9. Ухвала Вищого спеціалізованого суду із розгляду цивільних та кримінальних справ від 14 квітня 2015 року [Електронний ресурс] // Режим доступу до ресурсу: http:/www.reyestr.court.gov.ua/Review/ 43626016.

10. Ухвала Вищого спеціалізованого суду із розгляду цивільних та кримінальних справ від 13 листопада 2014 року [Електронний pecypc] // Режим доступу до ресурсу: http://www.reyestr.court.gov.ua/ Review/42766411

11. Моткова О. Право на життя у рішеннях Конституційного Суду України та Свропейського суду з прав людини / О. Моткова // Вісник Конституційного суду України - 2015 - № 1 - С. 49-59.

12. Byelov Dmytry. Ochrana l'udských a občianskych práv a slobôd advokácie na Ukrajine / Dmytry Byelov // Ludské práva včera a dnes 
pôvod a význam l’udských práv a ich ochrana v právnej teórii i praxi : Medzinárodná vedecká konferencia „Banskobystrická škola právnych dejín“ 3. ročník (Univerzita Mateja Bela, Právnická fakulta BANSKÁ BYSTRICA, 15. - 16. marca 2017). - S. 15-19.

13. Бєлов Д.М. Система міжнародної кримінальної юстиції та захист основоположних прав людини: окремі аспекти // Реформування законодавства Укрїани та розвиток суспільних відносин в Україні: питання взаємодії: Матеріали міжнародної науково-практичної конференції, м. Ужгород, 17-18 лютого 2017 року - м. Ужгород: Ужгородський національний університет, 2017 - С. 201-208.

14. Byelov Dmytry Enforcement of the constitutional right of the individual to information in social networks / Dmytry Byelov // Конституційно-правові академічні студії - 2017 - № 1 - С. 7-11.

15. Бєлов Д., Жежихова М., Роль та місце інституту адвокатури в механізмі захисту прав і свобод людини і громадянина / Д. Бєлов, М. Жежихова // Visegrad Journal on Human Rights: Vedecký časopis Fakulty práva Paneurópskej vysokej školy. - 2016. - № 5/1. - C. 19-26.

16. Громовчук М.В. Конституційно-правове закріплення евтаназії в зарубіжних країнах / М.В.Громовчук // Конституційно-правові академічні студії. - 2016. - № 2. - С.32-38.

17. Громовчук М.В. Конституційна система захисту прав і свобод людини та громадянина: питання теорії / М.В. Громовчук // Конституційно-правові академічні студії. - 2017. - № 1 - С. 18-26.

18. Громовчук М.В. Евтаназія в зарубіжних країнах: окремі питання конституційно-правового закріплення / М.В. Громовчук // Реформування законодавства України та розвиток суспільних відносин: питання взаємодії Матеріали Міжнародної науково-практичної конференції (21-22 квітня 2017 року, м. Ужгород). - С. 15-21.

\section{Information about the authors: Hromovchuk M. V.,}

Candidate of Juridical Sciences, Associate Professor, Department of Constitutional Law and Comparative Law, Law Faculty, Uzhhorod National University 4, Narodna sq., Uzghhorod, 88000, Ukraine Rohach O. Ya., Doctor of Juridical Sciences, Professor, Vice-Rector for Academic Policy and Research,

Uzhhorod National University 4, Narodna sq., Uzghhorod, 88000, Ukraine 